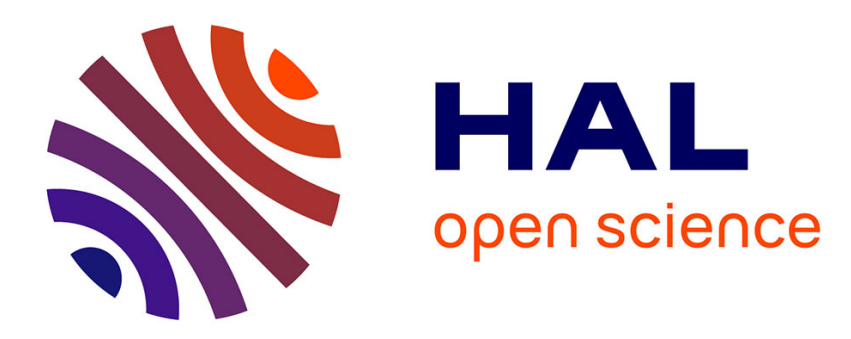

\title{
Philosophical Accounts of Biological Functions
}

Maël Montévil

\section{To cite this version:}

Maël Montévil. Philosophical Accounts of Biological Functions. 2017, pp.1071-1073. 10.1007/s11191017-9917-z . hal-02398767

\section{HAL Id: hal-02398767 https://hal.science/hal-02398767}

Submitted on 8 Dec 2019

HAL is a multi-disciplinary open access archive for the deposit and dissemination of scientific research documents, whether they are published or not. The documents may come from teaching and research institutions in France or abroad, or from public or private research centers.
L'archive ouverte pluridisciplinaire HAL, est destinée au dépôt et à la diffusion de documents scientifiques de niveau recherche, publiés ou non, émanant des établissements d'enseignement et de recherche français ou étrangers, des laboratoires publics ou privés. 


\title{
Philosophical accounts of biological functions ${ }^{\text {th }}$
}

\author{
Review of: Justin Garson (2016) A critical overview \\ of biological functions. Springer International Publish- \\ ing, Dordrecht. ISBN: 978-3-319-32020-5, 113 pages, \\ price: $\$ 54.99$ (paperback).
}

\author{
Maël Montévil ${ }^{\mathrm{a}, \mathrm{b}}$ \\ "Laboratoire "Matière et Systèmes Complexes" (MSC), UMR 7057 CNRS, Université Paris 7 Diderot, Paris, \\ France \\ ${ }^{b}$ Institut d'Histoire et de Philosophie des Sciences et des Techniques (IHPST) - UMR 8590, 13, rue du Four, 75006 \\ Paris, France
}

The book $A$ critical overview of biological functions is a short monograph by J. Garson, which provides a survey of the views on biological functions in the analytic tradition of philosophy. The notion of function is ubiquitous in biology and all of its subfields. Behind the notion of biological functions lurks the shadow of final causes. Overcoming this shadow is a challenge that has stimulated many philosophers and the literature on this topic is very rich. In the analytic tradition, researchers focus on providing naturalized accounts of functions. To do so, the main difficulty is to provide accounts of functions that exclude the use of final causes. The outcome of this collective work is a diversity of accounts of functions. Some of these accounts are fairly recent while others have been proposed several decades ago and are the object of many discussions.

Overall, the author provides an impressive and concise review of the debate on the various accounts of functions that are held by recent and current philosophers. The focus is on biological functions, and artifacts are discussed only inasmuch as some accounts

\footnotetext{
${ }^{t}$ Published as: Montevil, M. (2017). Philosophical accounts of biological func- tions. Science $\mathcal{E} E d-$ ucation. doi: 10.1007/s11191-017-9917-z. Book review of Justin Garson (2016) A Critical Overview of Biological Functions. Springer.

Email address: mael.montevil@gmail.com (Maël Montévil)

$U R L:$ http://montevil.theobio.org (Maël Montévil)
}

aim to theorize functions in both domains together. The core chapters of the book, chapters 2 to 6 , focus on the different accounts of functions. The first kind of accounts is discussed in chapter 2 and defines functions on the basis of goal-directedness, either from a behaviorist perspective in the case of Sommerhoff and Braithwaite or from a mechanistic perspective in the case of Nagel and the cyberneticists. Both families of accounts pertain to the history of philosophy in the sense that they have been the object of severe criticism and are no longer at the forefront of current debates. A second approach is developed in chapter 3 and is called the selective account of function. This account builds on the idea that a trait is functional when it has been selected in a population. This account has been introduced independently by Neander and Millikan and has been further developed by many philosophers such as Godfrey-Smith and Griffiths. In chapter 4, the author presents a third kind of accounts, which aims to define the function of a trait on the basis of its contribution to present day fitness. Boorse's account of function typically falls in this category. The fourth kind of accounts, in chapter 5 , grounds functions on their causal role in a system. This view has been introduced by Cummins and further developed by Craver and Davies among others. Last, chapter 6 presents three accounts of functions that are more recent. In particular, the author discusses the organizational account of functions sensu Moreno, Mossio 
and Saborido, an account that this reviewer contributed to develop. In a nutshell, this account states that particular theoretical entities that we call constraints are functional when they are interdependent parts of an organized whole.

In providing this survey, the author adopts a critical stance and he "make[s] no attempt to conceal [his] own viewpoint or to pretend to neutrality (p.11)." In spite of his defense of pluralism, the author clearly favors the selective account of functions and the corresponding chapter is more than twice longer than the other chapters. This bias is not an issue per se, especially because it is clearly stated in the beginning of the book. Nevertheless, we find that the motivations, the backgrounds or the strengths of other accounts are not as developed as their limitations. Sadly, this restricts the interest of the book when considered as a survey. In spite of this weakness, this book should be very helpful as a reference map of the accounts defended in current literature and as an introduction to the field.

In this context, the author discusses pluralism where pluralism means that different accounts of function may be simultaneously acceptable. He criticizes "betweendiscipline pluralism,' which seeks to restrict the applicability of the selected effect theory to some branches of evolutionary biology (p.109)." We share the idea that functions as selected effects are relevant to all fields of biology including, for example, physiology and development. Let us illustrate this point with examples that are not covered in the book. The notion of selective effect function is necessary to several biophysical models, which goes against the idea that these models would be only about proximal causes and would be independent or at least disjoint from ultimate causes. Let us mention two examples. The first example comes from the work of West, Brown and Enquist who developed models of lung and vascular physiology to understand allometric relationships of the metabolism. In these models, the authors assume that the function of lungs is to exchange oxygen meaning that oxygen ex- change rate have been optimized by natural selection. This assumption is required for the model to make predictions and reach its explanatory aim. To understand the second example, let us recall that two unrelated parameters, describing for instance the activation energy of different molecules, cannot be assumed to be equal without a reason. When developing a model of chromatin published in 2006, Lesne and Victor require such an equality for the system to perform its function. Since this equality cannot be considered as the result of randomness, it is justified on the ground of selection.

In spite of the relevance of selective effects functions in other fields than evolutionary biology, cross-disciplinary pluralism on accounts of functions raises questions that are not clearly solved. In particular, proving that a trait clearly comes from selection is a difficult task and leads to a heavy epistemological burden for fields which do not focus on this very question. In the examples above, selection is used to justify mathematical assumptions but the validity of this rational is not proven empirically. The author acknowledges this difficulty but does not really hint at solutions for practitioners.

The book uses a few running examples that are biologically sound and help understand the discourse without adding unnecessary complexities. However, the commitment of the author to the selective account of functions can sometimes be misleading in the treatment of these examples. For example, the author considers absurd the notion that the function of the nose is to support glasses. The article "the" makes sense in the selective account because this account focuses on the historical origin of a trait. But from other points of view, such as the organizational account of functions, a constraint may very well have many functions, and it is fair to say that $a$ function of the nose is to support glasses for some humans. Moreover, such statements are at home, for example, in Lotka's view that a proper aspect of human evolution is a heavy trend towards exosomatisation, that is to say, the development of inorganic "organs" such as glasses. 
We think that philosophical accounts of functions in biology depend strongly on their articulation to a theoretical framework. For example, the emphasis on selection stems from (Neo-) Darwinism. Similarly, the organizational account of function is based on a series of work from Kauffman, Varela, Rosen, among others, which aim to provide a theoretical account of the relationship between the part and the whole, a central notion to physiology. In this account, it is ultimately the circularity in the interdependence of constraints that grounds functionality. Then, the functionality holds with respect to this circularity: a part is functional for the larger entity defined by the circularity considered (Montévil \& Mossio, 2015, Biological organisation as closure of constraints). We fear that the author missed this rationale when designing counter-examples. For example, he considered that obesity or panic attacks are part of causal loops that ultimately maintain themselves and as a result would be functional. This should be absurd because these situations are pathological. However, these circularities do not involve the "bulk" of the organism and, as such, it is not sound to call them functional for the organism in the organizational account. Moreover, it is not clear whether they are constraints sensu Montévil \& Mossio.

Overall this book provides a good introduction to the debate on functions in analytic philosophy, and our criticism should be mitigated by the breadth of the literature considered and the short size of the book. We advise it mostly for a philosophical readership, as a map of the field. It is also possible for the philosophically-inclined biology teacher to use it as a reference when aiming to dispel the specter of final causes in her teaching, although this readership is clearly not the main target of this book. 